\title{
SELECTION OF EUCALYPT CLONES WITH HIGHER STABILITY IN PULP YIELD
}

\author{
Thaise da Silva Souza ${ }^{2 *}$, Bruno Marco de Lima $^{3} \odot$, José Luis Lima $^{3} \odot$, Aurelio Mendes Aguiar ${ }^{3}$, Donizete \\ da Costa Dias $^{3} \odot$, Gabriel Dehon Sampaio Peçanha Rezende ${ }^{3} \cdot$ and Magno Antonio Patto Ramalho ${ }^{4}$
}

\footnotetext{
${ }^{1}$ Received on 18.03.2019 accepted for publication on 03.12.2019.

${ }^{2}$ Universidade Federal de Lavras, Programa de Pós-Graduação em Genética e Melhoramento de Plantas, Lavras, MG - Brasil. E-mail: $<$ thaisefloresta@gmail.com>.

${ }^{3}$ Suzano S.A, Centro de Tecnologia, Jacareí, SP - Brasil. E-mail: <bmarcolima@gmail.com>, <jose.luis.lima@suzano.com.br>, <aurelio. aguiar@suzano.com.br>,<donizete.dias@suzano.com.br> and <gdehon@hotmail.com>.

${ }^{4}$ Universidade Federal de Lavras, Departamento de Biologia, Lavras, MG - Brasil. E-mail: <magnopatto@gmail.com>.

*Corresponding author.
}

\begin{abstract}
Forest exploitation is conducted in thousands of hectares in Brazil and presents a wide variation in environmental conditions in terms of soil, climate and even management, so identifying clones that may be recommended for these various conditions is a major challenge. In this recommendation, one important character is the mean annual increment in cellulose (MAICEL). This study aimed to evaluate the interaction of different clones and environments for $M A I C E L$ in order to verify whether the origin of clone selection affects their performance in other regions and to identify clones based on adaptability. MAICEL data were used for the evaluation of clones from Suzano S.A. in five environments distributed in the states of Espírito Santo, São Paulo, and Mato Grosso do Sul. Clonal tests were arranged in a randomized block design with plots of one plant. Data on MAICEL of the trees at five years were submitted to analysis of variance per environment and, subsequently, to the joint analysis. The clones $\mathrm{x}$ environments interaction was expressive for MAICEL, however, the origin of selection does not affect the performance of clones when grown in other regions. Some clones stood out for their adaptability, allowing more security to the company on the recommendation for different environments.
\end{abstract}

Keywords: Eucalypt breeding; Wood quality; Clones x environments interaction.

\section{SELEÇÃO DE CLONES DE EUCALIPTO COM MAIOR ESTABILIDADE NA PRODUTIVIDADE EM CELULOSE}

RESUMO - A exploração florestal é conduzida em milhares de hectares e apresenta ampla variação nas condições ambientais em termos de solo, clima e até mesmo manejo, assim, identificar clones que possam ser recomendados para essas diversas condições é um grande desafio. Nesta recomendação, um caráter importante é o incremento médio anual em celulose (IMACEL). Este estudo teve como objetivo avaliar a interação de diferentes clones e ambientes para o IMACEL com a finalidade de verificar se a origem da seleção dos clones afeta seu desempenho em outras regioes e identificar clones com base na adaptabilidade. Foram utilizados dados de IMACEL referente à avaliação de clones de Eucalyptus da empresa Suzano S.A. em cinco ambientes, nos estados do Espírito Santo, São Paulo e Mato Grosso do Sul. Os testes clonais foram instalados no delineamento de blocos casualizados com parcelas de uma planta. Dados referentes ao IMACEL das árvores, aos cinco anos, foram submetidos à análise de variância por ambiente e, posteriormente, à análise conjunta. A interação clones $x$ ambientes foi expressiva para o IMACEL, porém, a origem de seleção dos clones não afeta o seu desempenho quando utilizados em outras regiões. Alguns clones se destacaram quanto à adaptabilidade, permitindo maior segurança à empresa na recomendação para diferentes ambientes.

Palavras-Chave: Melhoramento de eucalipto; Qualidade da madeira; Interação clones x ambientes.

SIF $(x)$ EY
Revista Árvore 2020;44:e4403

http://dx.doi.org/10.1590/1806-908820200000003 


\section{INTRODUCTION}

The continued success of eucalypt plantation in Brazil depends on the selection of new clones that present better phenotypic expressions for traits of greater economic importance than pre-existing clones. Some steps must be overcome in the identification of these genotypes, and one of the most important is the final evaluation before its recommendation for forest exploitation.

This last step is fundamental, especially considering the diversity of the environmental conditions of eucalypt cultivation in the country. In this situation, the question is whether the clones evaluated under certain conditions may present a coincident behavior in another condition and what is sought is to identify those that are more adapted and stable. In this context, a large number of studies have already been carried out, with reference to the volume of wood produced, estimating the contribution of the clones $\mathrm{x}$ environments interaction to the total variation, and applying different methodologies to identify the most stable and adapted clones (Souza et al., 2017; Pupin et al., 2015; Santos et al.; 2015).

However, forest exploitation for pulp yeld is not only focused on the clones with the highest volume of wood, but on those that provide the largest amount of pulp produced, as well as others qualitative characters. One of the parameters widely used by forestry companies is the mean annual increment in cellulose - MAICEL. This index includes the volume of wood and also relates the variables basic density, pulp yield and specific wood consumption, reflecting the amount of cellulose that can be produced. Thus, the estimation of the contribution of the interaction to MAICEL and, above all, the identification of the most adapted and stable clones considering this index is fundamental.

Few papers report the analysis of genotypes by environments interaction considering wood quality characteristics in Brazil. Nunes et al. (2016) studied the indirect selection and the establishment of breeding zones using the basic density-productivity trait of eucalyptus clones in four environments in the State of Rio Grande do Sul. However, to date, no reports of possible clones $\mathrm{x}$ environments interaction have been found for MAICEL. Considering that the Brazilian pulp producers carry out the evaluation of clones in the final stage of the process and under experimental conditions different from those that the clones were obtained, it would be desirable to obtain more detailed information of the clones $\mathrm{x}$ environments interaction in MAICEL, to verify the possibility of generalizing recommendations.

In this context, this study aimed to evaluate the interaction of different clones and environments for MAICEL, to verify if the origin of clone selection affects its performance in other regions and to identify clones based on adaptability.

\section{MATERIAL AND METHODS}

Data of growth and wood quality of 13 Eucalyptus clones from the company Suzano S.A. of different species and selection origins were used. The selection origin corresponds to the region where the clone was selected (mega-environments), they are: Aracruz (ARA), Jacareí (JAC) and Três Lagoas (TLS). Six clones were selected in ARA (clones 1, 2, 3, 4, 5 and 6), three at JAC (clones 8, 9 and 11) and four at TLS (clones 7, 10, 12 and 13). Clones 1 and 7 are $E$. grandis, clones 8, 10 and 12 are E. urophylla, clones 2, 3, 4, 9, 11 and 13 are E. grandis x E. urophylla, clone 5 is E. urophylla x E. dunnii and clone 6 is $E$. urophylla x E. maidenii.

The clones were evaluated in five experiments involving the states of Espírito Santo (ES), São Paulo (SP) and Mato Grosso do Sul (MS): environment A corresponds to the experiment located in Aracruz-ES (19 51 '02"S; 4004'02"W) - ARA; environments $\mathrm{B}$ and $\mathrm{C}$ correspond to experiments located in Itapetininga-SP $\left(23^{\circ} 35^{\prime} 17^{\prime \prime} \mathrm{S} ; 48^{\circ} 02^{\prime} 54^{\prime \prime} \mathrm{W}\right)$ and Jacareí-SP (2317'52'’S; 45 $\left.57^{\prime} 57^{\prime \prime} \mathrm{W}\right)$ - JAC, respectively; and environments $\mathrm{D}$ and $\mathrm{E}$ correspond to the experiments located in Três Lagoas-MS (2047'14'S; 51 $51^{\circ} 42^{\prime} 13$ ' $\left.\mathrm{W}\right)$ and Selvíria-MS (20²1'44' 'S; 51 $\left.25^{\circ} 14^{\prime \prime} \mathrm{W}\right)$ - TLS, respectively.

The experiments were implemented in 2010, in a randomized block design, with plots of one plant (single tree plot) and 30 or 40 repetitions. The spacing used was $3 \mathrm{~m} \times 3 \mathrm{~m}$ in all locations.

For the analysis, the mean annual increment in cellulose (MAICEL), given in tons, was estimated by the following estimator (Equation 1):

MAICEL $=\frac{M A I}{S C}$

Revista Árvore 2020;44:e4403 
in which the mean annual increment (MAI), $\mathrm{m}^{3}$ / ha/year, was obtained by the estimator (Equation 2):

$$
M A I=\frac{V}{a} * k
$$

where a represents the age in years and the constant $k$ is the number of trees per hectare. MAI was multiplied by 0.87 to discount the percentage of bark and other elements present in the wood that are not important for the production of pulp. Volume $(\mathrm{V})$, given in $\mathrm{m}^{3} /$ tree, was estimated from measures of circumference at breast height converted to diameter at breast height $(\mathrm{DBH})$ in centimeters and height of trees (h) in meters, by (Equation 3):

$V=\frac{\pi D B H^{2}}{40000} * h * f$

where $\pi$ corresponds to 3.1416 and is a generic form factor used by the company, corresponding to 0.46 .

$S C$ corresponds to specific wood consumption, given in $\mathrm{m}^{3} /$ ton, and was obtained by the following estimator (Equation 4):

$$
\mathrm{SC}=\frac{90000}{B D W * P Y * 0.95}
$$

In that, BDW is the basic density of wood, given in $\mathrm{kg} / \mathrm{m}^{3}$, and $\mathrm{PY}$ corresponds to the pulp yield, given in percentage $(\%)$.

Data on MAICEL of the five-year-old eucalypt clones were tested by analysis of variance per environment. Subsequently, with the mean values, a joint analysis was performed involving all environments, using the following statistical model (Equation 5):

$$
Y_{i j}=\mu+C_{i}+E_{j}+C E_{i j}+e_{i j}
$$

Where: $Y_{i j}$ : observed value of clone $\mathrm{i}$ in environment $j ; \mu$ : constant; $C i$ : fixed effect of clone $\mathrm{i}$ $(i=1 \ldots 13) ; E_{j}$ : fixed effect of environment $j(j=1 \ldots 5)$; $C E_{i j}$ : fixed effect of the interaction between clone ${ }_{i}$ and environment $j ; e_{i j}$ : mean experimental error.

By means of the results of the analyses of variance in each environment, the accuracy (rgg')
(Resende and Duarte, 2007) was estimated according to (Equation 6):

$r g g^{\prime}=\sqrt{1-(1 / F)}$

The average performance of the clones was classified by the Scott and Knott (1974) test per environment and in the average of environments.

Subsequently, joint analysis of variance of all pairs of environments were run and the interaction was decomposed into simple and complex parts, according to methodology proposed by Cruz and Castoldi (1991).

The clones $\mathrm{x}$ environments interaction was also decomposed through the estimation of Ecovalence (W) (Wricke, 1965), by the estimator (Equation 7):

$W_{j}^{2}=\sum_{i=1}^{t}(g a)_{i j}^{2}$

Where corresponds to the sum of the squares of the effects of the interaction of clone $i$ with the environments $j$ on which it was evaluated.

The behavior of the clones in the different environments was also evaluated by the methodology of Nunes et al. (2005). For this, the mean data by environments were standardized by the estimator (Equation 8):

$$
z_{i j}=\frac{\bar{y}_{i j}+\bar{y}_{. j}}{s_{. j}}
$$

Where is the value of the standardized variable corresponding to clone $i$ in environment $j$, is the mean of clone $i$ in environment $j$, is the mean of environment $j$; and is the genotypic standard deviation between the means of the clones in environment $j$. Based on this same methodology, the risk of recommendation associated with each clone was estimated. For that, we used the sum of the absolute estimates of of the negative values. This value divided by the number of environments multiplied by the value of the constant, used to make positive all values, multiplied by one hundred, gives the percentage of the area below the mean, that is (Equation 9):

\section{Revista Árvore 2020;44:e4403}

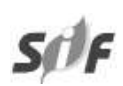


$R I=\frac{\left.\mid \sum Z \text { (Negative }\right) \mid}{\text { Number of Environements } * \text { Constant Added to } Z} * 100$

Eq.9

Where $R I$ is the risk of recommendation associated with each clone, in percentage.

The analyses were performed using statistical softwares R (R Core Team, 2016) and Genes (Cruz, 2013).

\section{RESULTS}

The accuracy estimates were all above 0.95 (data not shown). The estimates of the mean square error in the different environments were similar, that is, homoscedasticity of variances occurred, making it possible to perform the joint analysis of variance without restrictions.

In the joint analysis (Table 1), significant differences were detected between clones, environments and clones $\mathrm{x}$ environments interaction $(\mathrm{P} \leq 0.0001)$. Additionally, the source of variation (SV) clones was decomposed into clone origin and among clones within origin. Where the origin refers to clones that were selected in the region of Aracruz (ARA), Jacareí (JAC) and Três Lagoas (TLS). The SV origin

Table 1 - Joint analysis of variance of five environments for eucalypt MAICEL (t/ha/year) at five years. Effect of origins according to the selection origins of the clones (Aracruz (ARA), Jacareí (JAC) and Três Lagoas (TLS)).

Tabela 1 - Análise de variância conjunta de cinco ambientes para IMACEL de eucalipto (t/ha/ano) aos cinco anos. Efeito de origem de acordo com as origens de seleção dos clones (Aracruz (ARA), Jacareí (JAC) e Três Lagoas (TLS)).

\begin{tabular}{cccc}
\hline SV & DF & MS & P-value \\
\hline Environments (E) & 4 & 101.13 & $\leq 0.0001$ \\
Clones (C) & 12 & 52.96 & $\leq 0.0001$ \\
Origin of clones (O) & 2 & 29.19 & 0.2513 \\
ARA & 5 & 31.94 & 0.0175 \\
JAC & 2 & 47.14 & 0.0261 \\
TLS & 3 & 122.91 & 0.0013 \\
C x E & 46 & 11.58 & $\leq 0.0001$ \\
O x E & 8 & 20.09 & 0.4642 \\
ARA x E & 18 & 8.61 & $\leq 0.0001$ \\
JAC x E & 8 & 7.92 & $\leq 0.0001$ \\
TLS x E & 12 & 12.06 & $\leq 0.0001$ \\
Error & 1848 & 24.68 & - \\
\hline
\end{tabular}

was not significant. However, the SV within origin was significant, that is, there was variation in clone performance within each selection location.

Regardless of the region, the highest mean of clones was obtained in environment A (17.61 t/ha/ year) and the lowest was obtained in environment $\mathrm{E}$ (9.32 t/ha/year) (data not shown).

Analyses of variance of environment pairs were performed to better visualize the interaction between the forest exploitation sites of the company (Table 2). It was found that, in all pairs, the clones $\mathrm{x}$ environments interaction was significant $(\mathrm{P} \leq 0.0001)$. Estimates of the correlation between clone means in environment pairs were relatively low, except in the two environments of Três Lagoas ( $\mathrm{D}$ and $\mathrm{E}$ ), where the estimated correlation between clone means in these two environments was high.

The existence of the clones $\mathrm{x}$ environments interaction is best seen in Table 3 . The clustering of the clones by the Scott and Knott (1974) test was quite different between the environments and the nonagreement in the classification occurred both between and within the regions. Clone 7, selected in TLS, was the only one included in the group that presented the best performance in all environments (Table 3 ). This clone presents a considerable contribution to the interaction $(7.85 \%)$ because it had very distinct behavior, in reality (Figure 1). This is a typical situation in which the breeder can use the interaction to his benefit. Also worth mentioning are clones 2

Table 2 - Joint analysis of variance, G x E interaction into simple and complex parts and correlation coefficient $(\mathrm{R})$ in pairs of environments for eucalypt MAICEL ( $\mathrm{t} / \mathrm{ha} /$ years) at five years.

Tabela 2 - Análise de variância conjunta, interação $G \times A$ em partes simples e complexa e coeficiente de correlação (R) para os pares de ambientes para IMACEL de eucalipto (t/ha/ano) aos cinco anos.

\begin{tabular}{ccccc}
\hline Environments & P-value & Simple (\%) & Complex (\%) & $\mathrm{R}$ \\
\hline A x B & $\leq 0.0001$ & 17.56 & 82.44 & 0.25 \\
A x C & $\leq 0.0001$ & 0.55 & 99.45 & -0.04 \\
A x D & $\leq 0.0001$ & 32.80 & 67.20 & 0.40 \\
A x E & $\leq 0.0001$ & 36.36 & 63.64 & 0.46 \\
B x C & $\leq 0.0001$ & 60.74 & 39.26 & 0.70 \\
B x D & $\leq 0.0001$ & 73.62 & 26.38 & 0.79 \\
B x E & $\leq 0.0001$ & 62.06 & 37.94 & 0.66 \\
C x D & $\leq 0.0001$ & 32.92 & 67.08 & 0.58 \\
C x E & $\leq 0.0001$ & 24.10 & 75.90 & 0.41 \\
D x E & $\leq 0.0001$ & 69.15 & 30.85 & 0.89 \\
\hline
\end{tabular}

Revista Árvore 2020;44:e4403 
and 4 of ARA origin, clone 11 of JAC and clone 13 of TLS. They also presented the best classifications considering the five environments simultaneously (Table 3), which shows that although there was interaction of clones within each origin of selection, it was possible to identify clones that presented good performance in all environments of cultivation of the company. The environments A belonging to the region of ARA and $\mathrm{B}$ belonging to the region of JAC contributed the most to the $\mathrm{G} \times \mathrm{E}$ interaction.

Adaptability and stability of the clones evaluated are illustrated in figure 2. Clones 2, 7, 11 and 13 fit into the "full ball" behavior, i.e., with performance above the overall mean with small fluctuations between environments. Clones 1, 5, 6 and 10 show a typical "slack ball" behavior, that is, with performance below the mean and usually with large fluctuations between environments.

Based on this same methodology (Nunes et al., 2005), the risk of recommendation associated with each clone was calculated. Clones 1, 5, 6, 9 and 10 are not adapted, even in the selection region, and evidently, their recommendation involves enormous risk. As already pointed out, clones 2, 7,11 and 13 are those with the lowest risk of recommendation.

\section{DISCUSSION}

The accuracy estimates, all above 0.95, show the high precision with which the experiments were conducted in different environments (Resende and

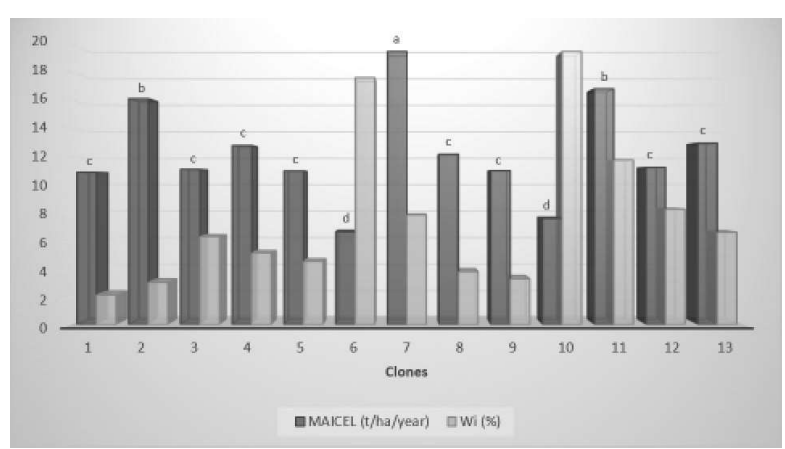

Figure 1 - Mean pulp yield - MAICEL ( $\mathrm{t} / \mathrm{ha} /$ year) obtained by eucalypt clone. Means followed by the same letter belong to the same group by the Scott Knott (1974) test at $5 \%$ probability level. Mean percentage contribution of the clones to the $\mathrm{G} \times \mathrm{E}$ interaction, Ecovalence (Wi). Data on pulp yield at five years of age, obtained in the evaluation of 13 clones of eucalypt in five environments

Figura 1 - Produção média de celulose - IMACEL (t/ha/ano) obtida por clone de eucalipto. Médias seguidas pela mesma letra pertencem ao mesmo grupo pelo teste de Scott Knott (1974), ao nível de 5\% de probabilidade. Contribuição média dos clones para a interação $G \times A$, em porcentagem, Ecovalência (Wi). Dados de produção de celulose de eucalipto aos cinco anos, obtidos na avaliação de 13 clones em cinco ambientes.

Duarte, 2007). These results also allow to infer that there was a significant difference between the clones in all the experiments, a condition that is indispensable for what is proposed in this study.

In the joint analysis (Table 1), the source of variation clones decomposed among clones within origin was significant, indicating that the

Table 3 - MAICEL ( $\mathrm{t} / \mathrm{ha} /$ year) of eucalypt obtained in the evaluation of 13 clones in five environments at five years of age.

Tabela 3 - Produção média de celulose (t/ha/ano) de eucalipto obtida na avaliação de 13 clones em cinco ambientes aos cinco anos de

\begin{tabular}{|c|c|c|c|c|c|c|c|}
\hline \multirow[t]{2}{*}{$\overline{\text { Clone }}$} & \multicolumn{7}{|c|}{ Environments } \\
\hline & A & B & $\mathrm{C}$ & & $\mathrm{D}$ & E & \\
\hline 1 & $12.34 \mathrm{c}$ & $10.84 \mathrm{c}$ & 10.64 & $\mathrm{c}$ & $11.86 \mathrm{c}$ & 8.77 & $\mathrm{c}$ \\
\hline 2 & $23.45 \mathrm{a}$ & $16.02 \mathrm{~b}$ & 16.43 & $\mathrm{a}$ & $14.17 \mathrm{~b}$ & 10.52 & $\mathrm{~b}$ \\
\hline 3 & $16.47 \mathrm{~b}$ & $5.70 \mathrm{~d}$ & 10.94 & $\mathrm{c}$ & $11.25 \mathrm{c}$ & 11.13 & b \\
\hline 4 & $12.62 \mathrm{c}$ & $12.52 \mathrm{c}$ & 15.48 & $\mathrm{a}$ & $12.72 \mathrm{c}$ & 10.62 & $\mathrm{~b}$ \\
\hline 5 & $11.68 \mathrm{c}$ & $14.10 \mathrm{~b}$ & 11.33 & $\mathrm{c}$ & $9.57 \mathrm{~d}$ & 8.26 & $\mathrm{c}$ \\
\hline 6 & $-\quad-$ & $3.66 \mathrm{~d}$ & 14.23 & $\mathrm{~b}$ & $-\quad-$ & 2.08 & $\mathrm{e}$ \\
\hline 7 & $19.61 \mathrm{a}$ & $23.35 \mathrm{a}$ & 16.84 & $\mathrm{a}$ & $20.06 \mathrm{a}$ & 17.45 & $\mathrm{a}$ \\
\hline 8 & $19.45 \mathrm{a}$ & $11.45 \mathrm{c}$ & 13.18 & $\mathrm{~b}$ & $7.90 \mathrm{~d}$ & 8.90 & $\mathrm{c}$ \\
\hline 9 & $12.80 \mathrm{c}$ & $13.93 \mathrm{~b}$ & 9.73 & $\mathrm{~d}$ & $10.01 \mathrm{~d}$ & 8.59 & $\mathrm{c}$ \\
\hline 10 & $20.60 \mathrm{a}$ & $2.92 \mathrm{~d}$ & 3.31 & $\mathrm{e}$ & $6.94 \mathrm{~d}$ & 4.29 & $\mathrm{~d}$ \\
\hline 11 & $19.75 \mathrm{a}$ & $23.09 \mathrm{a}$ & 17.05 & $\mathrm{a}$ & $14.72 \mathrm{~b}$ & 9.47 & $\mathrm{c}$ \\
\hline 12 & $20.13 \mathrm{a}$ & $6.27 \mathrm{~d}$ & 9.21 & d & $11.36 \mathrm{c}$ & 9.22 & $\mathrm{c}$ \\
\hline 13 & $21.39 \mathrm{a}$ & $10.48 \mathrm{c}$ & 9.09 & $\mathrm{~d}$ & $12.19 \mathrm{c}$ & 11.67 & $\mathrm{~b}$ \\
\hline
\end{tabular}

Means followed by the same letter in each row belong to the same group by the Scott Knott (1974) test at 5\% probability level.

Médias seguidas pela mesma letra em cada linha pertencem ao mesmo grupo pelo teste de Scott Knott (1974), a 5\% de probabilidade. 
The red line represents the overall mean of the 13 clones evaluated and the black line represents the performance of the clone in question evaluated in the five environments (A, B, C, D and E).

A linha vermelha representa a média geral dos 13 clones avaliados e a linha preta representa o desempenho do clone em questão avaliado nos cinco ambientes (A, B, $C, D e E)$.
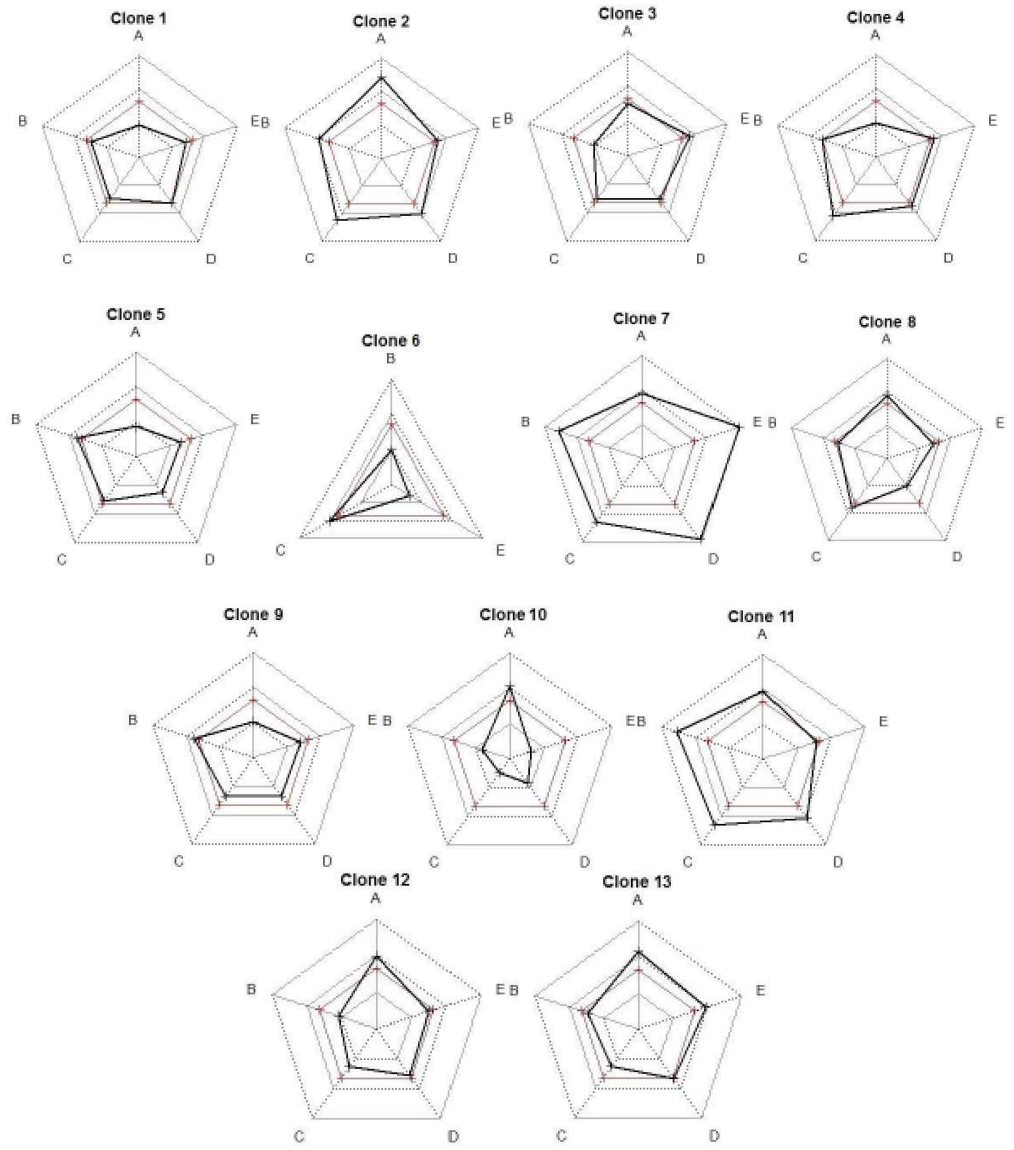

Figure 2 - Graphic representation of eucalypt pulp yield (MAICEL) of clones evaluated in five environments.

Figura 2 - Representação gráfica da produção de celulose (IMACEL) de clones de eucalipto avaliados em cinco ambientes.

site where the clone was obtained (origin) did not affect, on average, its performance in the different environments. From a practical point of view for the company, the site of origin of the clone does not restrict its recommendation to other sites in different regions. However, the clones obtained in each region had different behavior in the evaluated environments. Unfortunately, no reports have been found in this regard for eucalypt or any other perennial plant. The only information was obtained with the common bean and the results were different to those reported in this study, that is, the lines presented better performance at the site of their origin (Silva et al., 2011).

Considering that the interaction of the clones with the environments was significant, it can be inferred that the behavior of the clones was not coincident in the different environments for the pulp yield. Similar results were obtained when evaluating only the eucalypt growth variables in more environments and with a higher number of clones (Souza et al., 2017; Santos et al., 2015; Rocha et al., 2005; Nunes et al., 2002). No reports of clones $x$ environments interaction were found for MAICEL.

There are numerous methods to study better the interaction, including some more recently published (Farias Neto et al., 2018; Oliveira et al., 2018). Nevertheless, in this study we decided to use traditional and above all easy-to-interpret methods. It should be pointed out that it has been observed that the more sophisticated the method of analysis of

Revista Árvore 2020;44:e4403 
adaptability and stability the less is the repeatability of the information obtained (Mendes and Ramalho, 2018).

The analyses of variance of environment pairs (Table 2) make it possible to infer that the interaction was important and predominantly complex (Cruz et al., 2004; Vencovsky and Barriga, 1992; Cruz and Castoldi, 1991; Kang and Miller, 1984). In this condition, the classification of the clones varies between sites and the company must use clone recommendation strategies to mitigate the interaction in the production of pulp at each site. One of the alternatives currently used to mitigate interaction in eucalypt cultivation is the use of clonal composites. The use of eucalypt clonal composites framed by improved, phenotypically similar and unrelated clones may be an important strategy to help breeders prevent commercial eucalypt plantations from unpredictable future adverse events, as well as to promote sustainable productivity gains (Rezende et al., 2019). In this context, a viable strategy would be to associate clones 2, 7,11 and 13 and generalize their use to all planting environments from the company.

Considering that forest exploitation is carried out on thousands of hectares under very diverse environmental conditions, characterizing the environments allows finding regions that may be more similar and thus facilitating the execution of breeding programs despite the unpredictability of climatic conditions. When considering the pair of environments $\mathrm{D}$ and $\mathrm{E}$, between them, there was a predominantly simple interaction of low magnitude, showing that these environments allow to classify the clones in a similar way, forming a "breeding zone" (Resende, 2005). For the other environments, the evaluations should be intensified in order to identify clones with wider adaptation to facilitate the recommendation of new clones of the company.

The environments $\mathrm{A}$ and $\mathrm{B}$ belonging to the regions of Aracruz and Jacareí, respectively, contributed the most to the G x E interaction. These results indicate that the selection of these sites to conduct the experiments was relevant and should be maintained to select clones with greater phenotypic stability.

The variation for pulp yield was high $(9.32 \mathrm{t} / \mathrm{ha} /$ year to $17.61 \mathrm{t} / \mathrm{ha} /$ year) (Figure 1 ) which is a favorable condition to reach the objectives of the study (Pupin et al., 2015).

The clustering of the clones by the Scott and Knott (1974) test showed that the clones 2, 7, 11 and 13 presented the best classifications considering the five environments simultaneously (Table 3 ). For this reason, these clones were among those with best performance in the average of the five environments (Figure 1).

All these results are consistent with those already discussed in the joint analysis of variance (Table 1). However, when clones 7 and 11 from Três Lagoas and Jacareí, respectively, were analyzed in the different environments of the region, they were in the group that presented the best performance. Thus, even if interaction occurs and no effect of the region in which the clone was selected is detected, it is possible to identify clones in which their selection origin affects their performance.

Considering the contribution of clones to the interaction, the clone 6 should be discarded, since besides presenting high contribution to the interaction and low mean, it points out a huge risk of recommendation (Figure 2), since it is neither stable nor adapted.

Adaptability and stability of the clones evaluated showed that clones 2, 7, 11 and 13 presented performance above the overall mean with small fluctuations between environments (Figure 2). In other words, it is what is sought in forest exploitation. However, clones 1, 5, 6 and 10 show performance below the mean and usually with large fluctuations between environments, that is, are not adapted, even in the selection region, and evidently their recommendation involves enormous risk, since they are not stable. As already pointed out, clones $2,7,11$ and 13 are those with the lowest risk of recommendation. It is important to note, however, especially in perennial plants, that this information is valid for the different environmental conditions in which the clones were evaluated. The behavior in future years, even considering the sites of evaluation, has little predictability. Unfortunately, no reports of clones $\mathrm{x}$ years interaction involving any eucalypt trait were found. However, it can be assumed that this interaction should be high, which makes the recommendation of new clones very vulnerable. 


\section{CONCLUSIONS}

The variable MAICEL presents significant interaction of genotype with the environment, but the origin does not affect the performance of clones when grown in other regions. As for selection for adaptability, clones 2, 7, 11 and 13 may be recommended with lower risk for the company's logging regions.

\section{REFERENCES}

Allard RW, Bradshaw AD. Implications of genotypeenvironmental interactions in applied plant breeding. Crop Science. 1964;4:503-508.

Cruz CD. GENES - a software package for analysis in experimental statistics and quantitative genetics. Acta Scientiarum Agronomy. 2013;35(3):271-276. doi:10.4025/actasciagron.v35i3.21251

Cruz CD, Regazzi AJ, Carneiro PCS. Modelos biométricos aplicados ao melhoramento genético. 3 . ed. Viçosa, MG: UFV; 2004. ISBN: 9788572694339.

Cruz CD, Castoldi FL. Decomposição da interação genótipos x ambientes em partes simples e complexa. Revista Ceres. 1991;38(219):422-430.

Farias Neto JT, Yokomizo GKI, Oliveira MSP, Hongyu K. GGE biplot for stability and adaptability in assai palm trees progenies from Anajás, PA. Revista Agroambiente. 2018;12(1):25-33. doi: 10.18227/1982-8470ragro.v12i1.4220

Ferreira RADC, Ramalho MAP, Toledo FHRB, Abreu AFB. Implications of the number of years assessment on recommendation of common bean cultivars. Plant Breeding. 2015;134(5):599-604. doi: 10.1111/pbr. 12302

Kang MS, Miller JD. Genotype x environment interactions for cane and sugar yield and their implications in sugarcane breeding. Crop Science. 1984;24(3):435-440. doi: 10.2135/cropsci1984

Mendes MHS, Ramalho MAP. Repeatability of some phenotypic stability parameters $-\mathrm{a}$ resampling approach. Crop Breeding and Applied Biotechnology. 2018;18(2):139-147. doi: 10.1590/1984-70332018v18n2a20

Nunes ACP, Santos GA, Resende MDV, Silva LD, Higa AR, Assis TF. Estabelecimento de zonas de melhoramento para clones de eucalipto no Rio Grande do Sul. Scientia Forestalis. 2016;44(111):563-574. doi: $10.18671 /$ scifor.v44n111.03

Nunes JAR, Ramalho MAP, Abreu AFB. Graphical method in studies of adaptability and stability of cultivars. Annual Report of the Bean Improvement Cooperative. 2005;48:182-183.

Nunes GHS, Rezende GDSP, Ramalho MAP, Santos JB. Implicações da interação genótipos $\mathrm{x}$ ambientes na seleção de clones de eucalipto. Cerne. 2002;8(1):49-58. doi: 10.1590/S010384782011000100009

Oliveira TWG, Paula RC, Moraes MLT, Alvares CA, Miranda AC, Silva PHM. Stability and adaptability for wood volume in the selection of Eucalyptus saligna in three environments. Pesquisa Agropecuária Brasileira. 2018;53(5):611-619. doi: 10.1590/S0100204X2018000500010

Pupin S, Santos AVA, Zaruma DUG, Miranda AC, Silva PHM, Marino CL, et al. Produtividade, estabilidade e adaptabilidade em progênies de polinização aberta de Eucalyptus urophylla $\mathrm{S}$. T. Blake. Scientia Forestalis. 2015;43(105):127-134 doi: /10.18671/scifor.v43n105.02

Ramalho MAP, Abreu AFB, Santos JB, Nunes JAR. Aplicações da genética quantitativa no melhoramento de plantas autógamas. 1ed. Lavras: UFLA; 2012. ISBN: 9788581270104.

Rezende GDSP, Lima JL, Dias DC, Lima BM, Aguiar AM, Bertolucci FLG, et al. Clonal composites: an alternative to improve the sustainability of production in eucalypt forests. Forest Ecology and Management. 2019;449:117445. doi: 10.1016/201906042

Resende MDV. Melhoramento de Essências Florestais. In: Borém A. Melhoramento de Espécies Cultivadas. Viçosa, MG: Editora UFV; 2005. p. 717780. ISBN: 8572692061.

Resende MDV, Duarte JB. Precisão e controle de qualidade em experimentos de avaliação de cultivares. Pesquisa Agropecuária Tropical. 2007;37(3):182-194.

R Core Team. R: A Language and Environment for Statistical Computing. Vienna, Austria: R Foundation

Revista Árvore 2020;44:e4403 
for statistical Computing; 2016. URL: http://www.Rproject.org/

Rocha RB, Muro-Abad JI, Araújo EF, Cruz CD. Avaliação do método centróide para estudo de adaptabilidade ao ambiente de clones de Eucalyptus grandis. Ciência Florestal. 2005;15(3):255-266. doi: $10.5902 / 198050981863$

Santos GA, Resende MDV, Silva LD, Higa A, Assis TF. Interação genótipos $\mathrm{x}$ ambientes para produtividade de clones de Eucalyptus L'Her. no estado do Rio Grande do Sul. Revista Árvore. 2015;39(1):81-91. doi: 10.1590/010067622015000100008

Scott AJ, Knott M. A cluster analysis method for grouping means in the analysis of variance. Biometrics. 1974;30(3):507-512.
Silva CA, Abreu AFB, Ramalho MAP, Carneiro JES. Implicações da origem das linhagens de feijoeiro na magnitude da interação com ambientes. Pesquisa Agropecuária Brasileira. 2011;46(7):720-728. doi: 10.1590/S0100-204X2011000700007

Souza TS, Ramalho MAP, Lima BM, Rezende GDSP. Performance of Eucalyptus clones according to environmental conditions. Scientia Forestalis. 2017;45(116):601-610. doi: 10.18671/scifor. v45n116.01

Vencovsky R, Barriga P. Genética biométrica no fitomelhoramento. Ribeirão Preto: Sociedade Brasileira de Genética; 1992. 416 p.

Wricke G. Zur Berechnung der Ökovalenzbei Sommerweizenund Hafe R. Zeitschriftfür Pflanzenzüchtung. 1965;52(1):127-138. 